\title{
PERCEPTIONS OF MARITAL ROLES IN BASIC COMMODITY GROUPS PURCHASE DECISION-MAKING
}

\author{
Irina Kancheva ${ }^{1}$ \\ Georgi Marinov ${ }^{2}$
}

\begin{abstract}
Family plays a primary role in the demand formation in consumer markets worldwide. It is the field where a wide variety of consumer decisions are made every day. Family decisionmaking is a complex process in which multiple individuals combine their personal needs, wants and resources in order to reach a satisfactory outcome. The development of the social system leads to modifications of the known behavioral patterns of the family as a consumption unit. This paper is aimed at present-day Bulgarian family marital role structure. The distribution of roles between spouses was examined across 22 commodity groups using a convenience sample of 215 respondents.
\end{abstract}

Keywords: Marital Roles, Relative Influence, Family Purchase Decision, Family Decision-Making

JEL Codes: D03, D12, J12, R22

\section{Literature review}

Marketers and consumer researchers consider the family to be the most important decisionmaking and consumption unit (Assael, 1987). The division of roles within the family as an interactive decision-making system has been subject to intensive investigation over the last few decades. Most researches focus on the marital couple, due to the limited participation of children in decision-making processes for both everyday (Spiro, 1983) and complex family purchases (Lee and Levi, 2004).

Davis (1974) defines the roles within the family as "duties and responsibilities, that are assigned to positions". Family roles determine every individual's rights and obligations within the family group. The influence exerted by the spouses in decision-making processes defines the marital role structure. The distribution of marital roles is based on different factors, which can be external or internal for the family unit. Cultural role stereotypes, defining the attitudes towards the distribution of responsibilities between husbands and wives have been recognized as an external factor of marital roles distribution (Blood and Wolfe, 1960; Ford, 1995). A number of studies (Green and Cunningham, 1975; Rosen and Granbois, 1983; Qualls, 1987) discovered a significant relationship between sex-role orientation and relative influence in family decision-making. Putnam and Davidson (1987) found there was less sex-role dominance and the decisions were more autonomic for "less risky" purchases. The equalitarianism in Western societies has led to a shift towards joint or syncratic final decision (Davis and Rigaux, 1974, Bonfield, 1978). According to the stage of social development defining the sex-role orientation Rodman (1972) develops a typology

\footnotetext{
${ }^{1}$ University of Economics, Varna, Bulgaria, e-mail: irina_kancheva@abv.bg

${ }^{2}$ University of Economics, Varna, Bulgaria, e-mail: georgi.marinov@gmail.com
} 
of the societies as Patriarchy (male dominant), Modified Patriarchy, Transitional Equalitarianism and Equalitarianism (equity between males and females).

Internal factors of marital role distribution are the resources brought by each spouse into the marriage (Green at all, 1983) and involvement with the purchase (Webster, 1995). Resource theory postulates that the influence in the decision-making process is defined by the resources a spouse holds. These resources can be presented by their educational level, social and occupational status. Research in Western countries have supported this theory, while the influence of spousal resources is less important than the strong cultural norms in patriarchal societies. A study conducted in Greece and Yugoslavia found greater authority of the husbands in lower-class families, while upper class families tended to be egalitarian (Rodman, 1972).

Several studies have shown role specialization within families according to product category (Davis, 1974; Davis and Rigaux, 1974; Bonfield, 1978; Green at all, 1983; Webster, 1995), and within product categories, depending upon the product characteristic selected (Starch, 1958; Davis, 1970). Different product categories have been used in family roles research. The most common sets consist of 25 product categories (Davis and Rigaux, 1974, Bonfield, 1978; Webster, 1995; Ford et. all, 1995), and two major purchases - automobile and furniture (Davis, 1970; Shuptrine and Samuelson, 1976). Hopkins and Webster (2000) applied six commonly used low involvement and high involvement product categories extracted from previous studies to their research.

Jaffe and Senft (1966) discovered that the influence of the spouses in the decision-making process vary not only with the product but also with the stage of the decision making process. Shuptrine and Samuelson (1976) found out that neither spouse is completely dominant in the purchase decision, but each spouse is dominant in certain aspects of the purchase decision. Considerable specialization was found in the information search phase (Davis and Rigaux, 1974; Putnam and Davidson, 1987). Davis and Rigaux (1974) and Bonfield (1978) discovered that more than half of the decisions remain in the same pattern of influence during all phases of the decision process.

\section{The experiment}

In order to assess the distribution of marital roles in buying decisions of primary groups of products we carried out a study in the period March-May 2013. Our sample is non-representative for Bulgaria, but nevertheless we aim to encompass the major part of the country - we have 215 respondents from 56 places in Bulgaria. The respondents are 114 wives and 101 husbands from different families of 'traditional' (heterosexual) type, with a minimum of 2 years of family life experience. After revisioning the data we use a final sample of 113 wives and 99 husbands. A previous version of this paper was presented in September 2013 at an UNWE-Sofia conference.

We asked our respondents to fill in a questionnaire with direct questions about the relative importance of the respective family member in the decision-making process: the initial recognition of the need; the collection and classification of information about the possible alternatives and the making of the final choice for 22 groups of different goods and services. The groups are: cleaning products, kitchenware, children's clothing, wife's clothing, husband's clothing, food, cosmetics, nonprescription drugs, housing upkeep (maintenance), children's toys, tv, savings/financial instruments, car, life insurance, other insurance, entertainment, vacation, school, home, living room furniture, other furniture, alcoholic beverages.

We present the results on joint graphs for the women and men, respectively. On the graphs below on the horizontal axis we put the extent of role specialization in the family, that is how important is the role of the respective family member in the respective decision $(0-$ the man, $2-$ the woman, 1 - joint decision), and on the vertical axis is the degree of authonomy - values closer to 1 have decisions, judged as 'jointly taken', syncratic, and vice versa - decisions with values closer 
to 0 are assessed as autonomic ones. The answers of women are colored in red and are marked with circles, the answers of men are in blue and marked with triangles.

In (fig. nr. 1) are presented the marital roles in initial recognition of the need. The answers of women and men broadly coincide.

As strongly „wife-dominated“ are assessed products as cosmetics, cleaning products, kitchenware, non-presctiptive drugs etc. Our respondents assess as „husband-dominated“ cars, husband's clothing, alcohol, and tv. Furniture, insurances and home are marked by significant syncracy in the initial process of finding. Our results broadly comply with other studies, as the seminal Davis-Rigaux (1974) paper. Surprisingly, our respondents have divergent views about the financial decisions, home and furnitures. Anyway, the level of role consensus is relatively high.

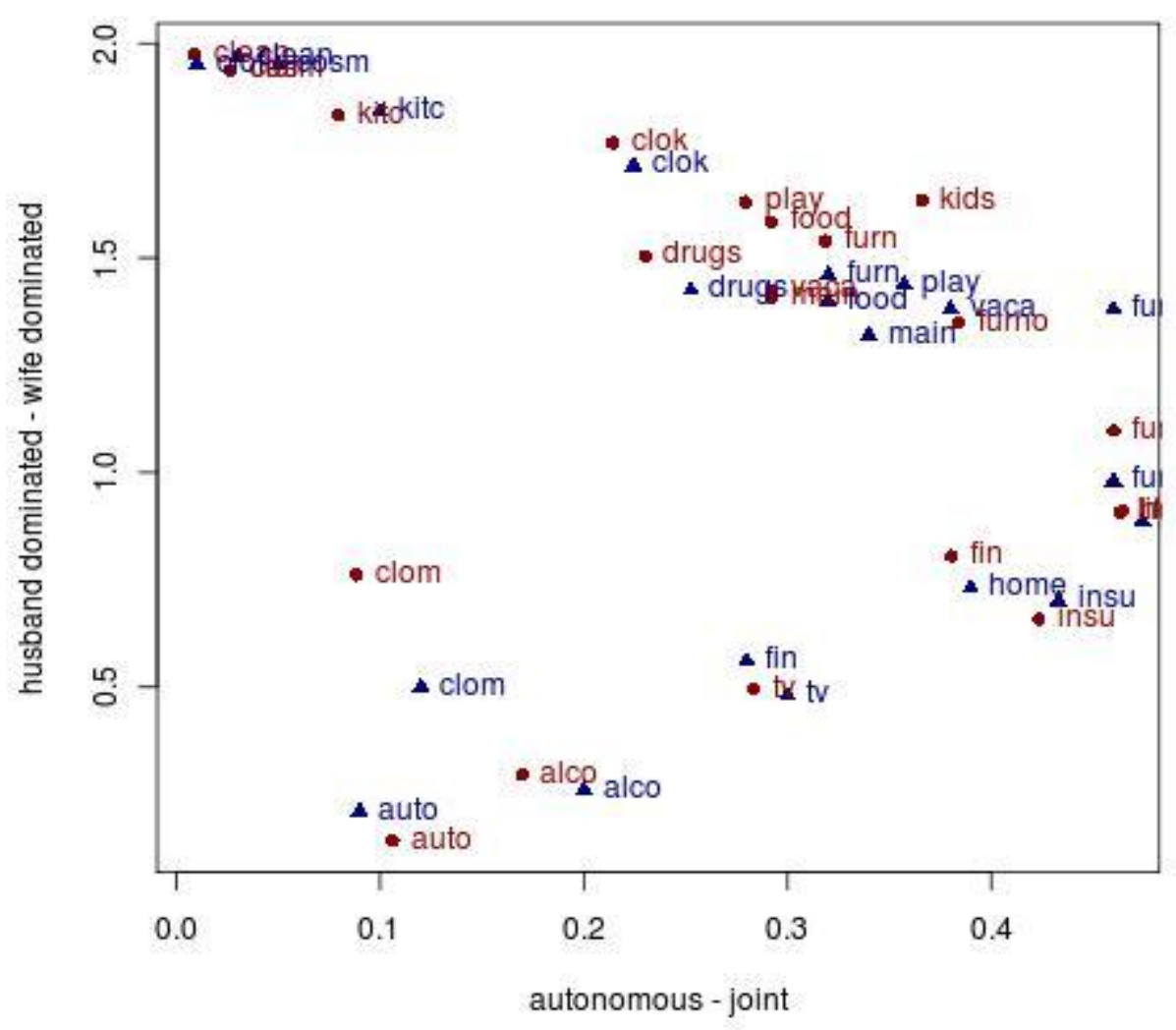

Figure no. 1 - „Who is the first to recognize the need for the respective product/service?"

Women prove to be more active in gathering and processing information about products and services. There is more consilience in the answers of our respondents. Even in groups as „home“, or „financial instruments“ wives are considered the more active partner. 


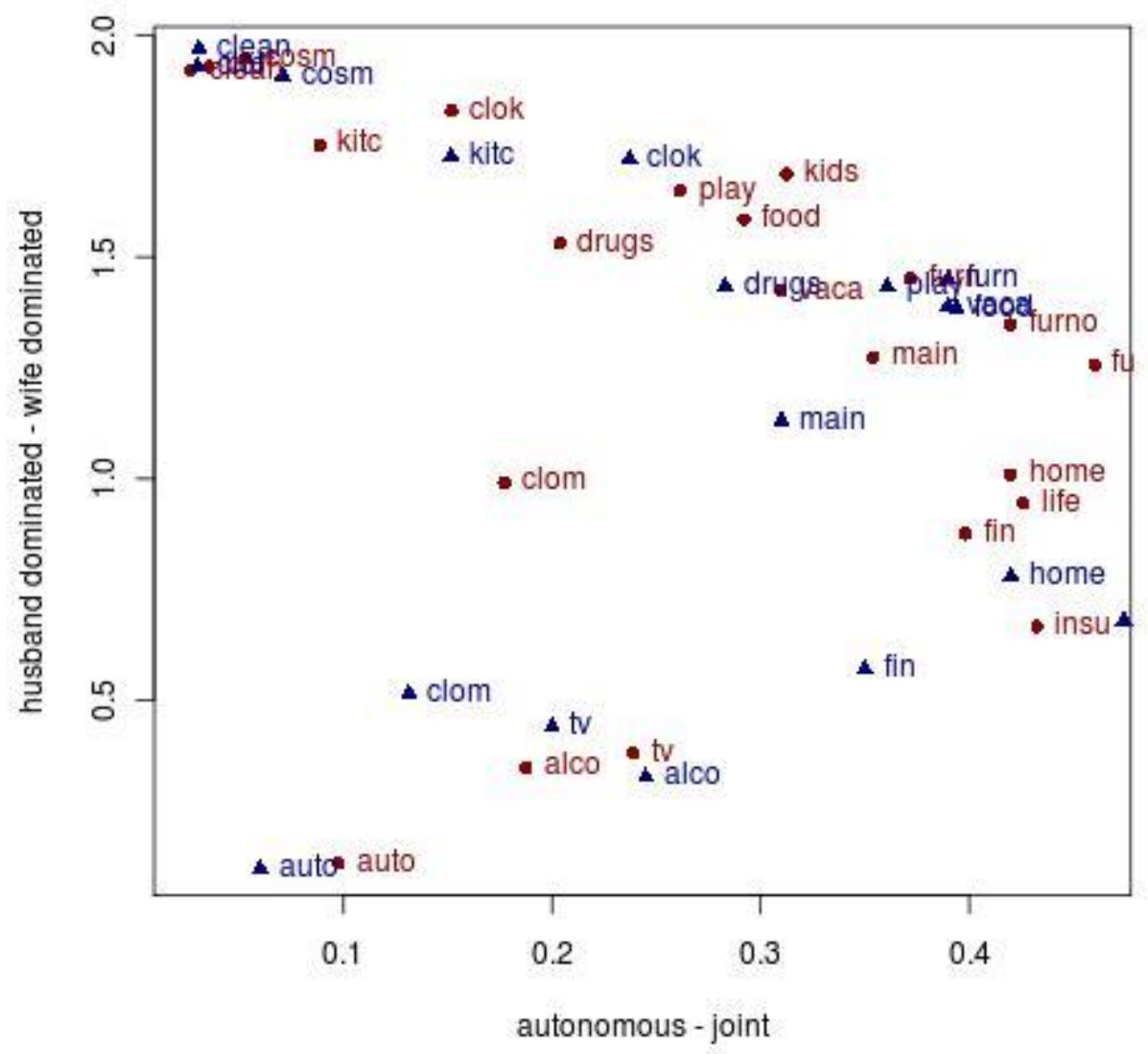

Figure no. 2 - ,Who is more active in gathering information about the alternatives for the respective product/service?" 


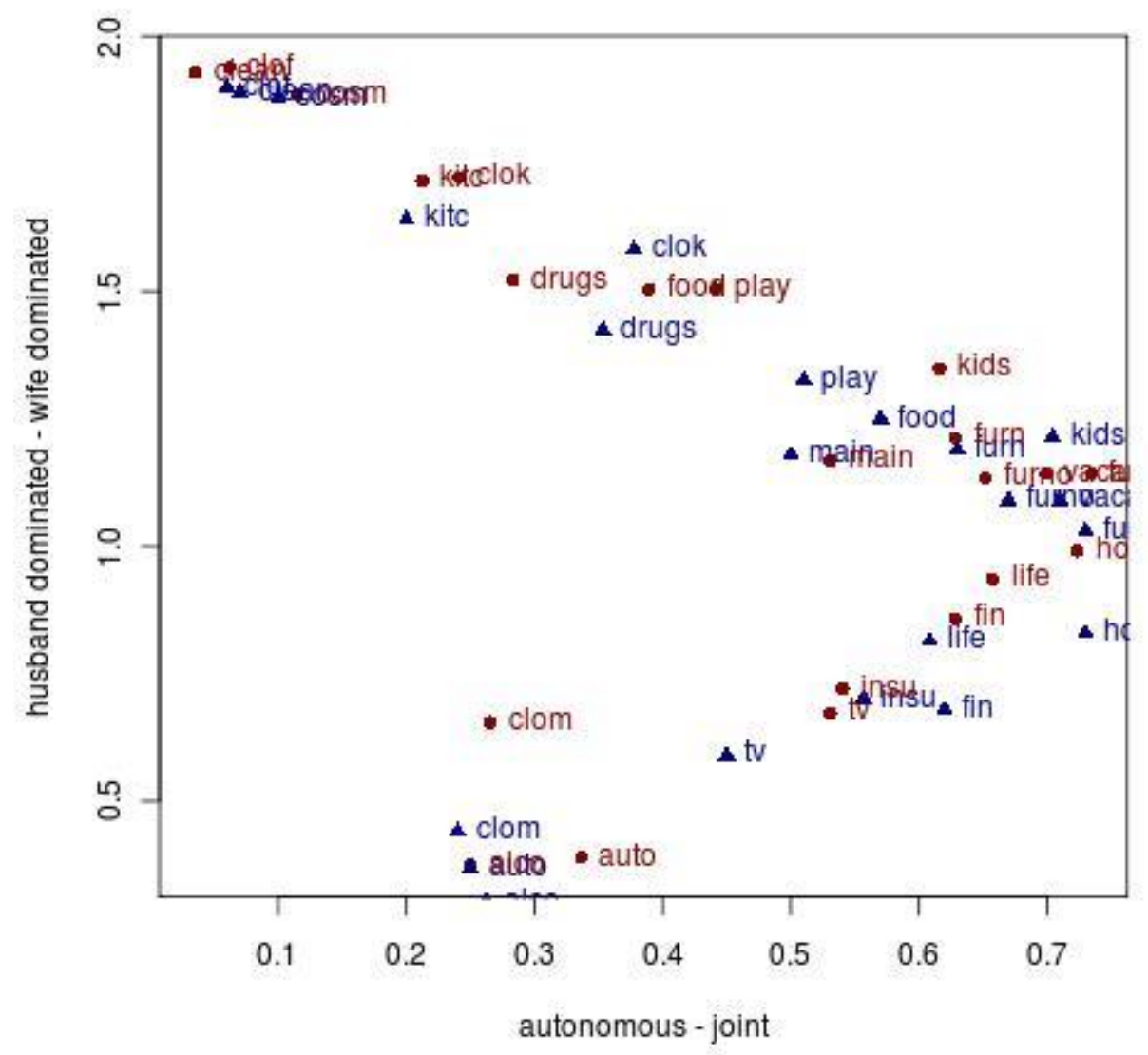

Figure no. 3 - ,Who makes the final decision of choosing and buying the product/service?“

In the final decision process syncracy grows - many of the final buying decisions are assessed as a matter of "joint decision" by our respondents. Especially interesting is the fact that there are virtually no husband-dominated autonomous decisions, and this fact indirectly supports the results of other studies of consumer behavior in Bulgaria (i.e. Stanimirov 2013).

Wives take an important role in final decisions, even in ,masculine“ products such as car, alcohol or husband's clothing.

Anyway, despite the syncracy, „financial“" products as insurances (life and other) and financial instruments are assessed as men-dominated. We attribute this to the fact that in Bulgaria there is a significant division of earnings - the nominal situation is that the husband in the family contributes more to the family budget.

There are some signs that the resource theory holds for Bulgaria, especially given the twofold character of adulthood.

\section{Conclusion}

Marital decision roles are an important clue for differencing and adjusting marketing techniques. Wife's influence in all the phases of decision-making is significant and cannot be neglected, especially in decisions about "long-term" products as house, financial instruments, life insurance and furniture, despite the husband's role in family resources. Views of respondents of both sexes broadly converge. 


\section{References:}

1. Assael H, 1974. Consumer Behaviour and Marketing Action. Melbourne, Thomas Nelson.

2. Blood R., Wolfe D., 1960. Husbands and wives: The Dynamics of Married Living. Glenhoe, Il., Free Press

3. Bonfield E. H., 1978. Perception of Marital Roles in Decision Processes: Replication and Extension, Advances in Consumer Research vol. 5

4. Davis, H. L., 1970. Dimensions of Marital Roles in Consumer Decision Making, Journal of Marketing Research vol. 7

5. Davis H. L., 1974. Family Decision Making as Conflict Management, Advances in Consumer Research, vol. 1.

6. Davis H. L., Rigaux B. P., 1974. Perception of Marital Roles in Decision Processes, Journal of Consumer Research Vol. 1.

7. Ford J., LaTour M., Henthorne T., 1995. Perceptions of Marital Roles in Purchase Decision Processes: A Cross-Cultural Study, Journal of the Academy of Marketing Research vol. 23, Nr. 2

8. Green R., Cunningham I., 1975. Feminine Role Perception and Family Purchase Decisions, Journal of Marketing Research vol. 12

9. Green R., Leonardi J. P., Chandon J. L., Cunningham I., Verhage B., Strazzieri A., 1983. Societal Development and Family Purchasing Roles: A Cross-national Study, Journal of Consumer Research vol. 9, pp. 436-442.

10. Hopkins C. D., Webster C., 2001. Resource Theory and Marital Decision-Making Power: The Utilization of an Hedonic Modeling Approach. In Suter, T. A. (Ed.) Annual meeting, Society for Marketing Advances conference; Marketing advances in pedagogy, process, and philosophy

11. Jaffe L. J., Senft H., 1966. The Roles of Husbands and Wives in Purchasing Decisions

12. Adler L., Crespi I. (Eds.), Attitude research at sea, Chicago, American Marketing Association

13. Lee C., Levi D., 2004. The Influence Of Family Members On Housing Purchase Decisions, Journal of Property Investment \& Finance, Vol. 22, Nr. 4

14. Putham M., Davidson, W. R., 1987. Family Purchasing Behavior II: Family Roles by Product Category. Columbus, $\mathrm{OH}$, Management Horizons, Inc.

15. Qualls W., 1987. Household Decision Behavior: The Impact of Husbands' and Wives'Sex Role Orientation, Journal of Consumer Research, Vol. 14

16. Rodman H., 1972. Marital Power and the Theory of Resources in Cross-Cultural Context, Journal of Comparative Family Studies, Vol. 1

17. Rosen D., Granbois, D., 1983. Determinants of Role Structure in Family Financial Management, Journal of Consumer Research, Vol. 10

18. Spiro R. L., 1983. Persuasion in Family Decision-Making, Journal of Consumer Research, Vol. 10

19. Stanimirov E., 2013. Methodological Aspects of the Study of Customer Satisfaction, Journal of International Scientific Publication: Economy \& Business, Vol. 7, Part 1

20. Starch D. and staff, 1958. Male vs Female Influence on the Purchase of Selected Products. New York, Fawcett publications.

21. Webster C., 1995. Determinants of Marital Power in Decision Making, Advances in Consumer Research, Vol. 22

22. Левкова И., 2004. Сценарно развитие в зрелостта. В. Търново, Фабер. 